\title{
Making sense of the story - The dialogues between the police and forensic laboratories in the construction of DNA evidence
}

Filipe Santos (filipesantos@ics.uminho.pt)

\begin{abstract}
:
The use of DNA technologies for criminal investigation purposes illuminates an interplay of knowledge and expertise where meaning and relevance of biological traces are negotiated. Through the analysis of five criminal cases that took place in Portugal between 1995 and 2010, and where DNA technologies were used, this article will focus on the dialogues established between the police and the forensic laboratories. I will argue that, on the one hand, the police investigators uses of DNA technologies seek to legitimate and provide an external source of neutrality and objectivity to the constructed narratives surrounding the commission of a crime. On the other hand, laboratories and forensic experts engage in the delimitation and preservation of their professional autonomy by developing boundary work around their scientific expertise through the translation and conversion of criminal traces into scientific artifacts.
\end{abstract}

Keywords: DNA; police; crime; forensic science; boundary work

This is an Author's Accepted Manuscript of an article published in New Genetics and Society, Volume 33, Issue 2, pp. 181-203 [copyright Taylor \& Francis], available online at: http://www.tandfonline.com/doi/pdf/10.1080/14636778.2014.916186

[DOI: 10.1080/14636778.2014.916186]." 


\section{Introduction}

This article draws from the analysis of five case studies of criminal cases that occurred in Portugal between 1997 and 2007. The wider aim of my investigation is to analyze the modes of the heterogeneous constructivism (Hess 1997) of DNA technologies in judicial contexts by focusing on the activities and discourses of the police, magistrates, forensic experts, lawyers, and also the journalistic coverage of the cases. The purpose of this paper focuses a particular element of the social construction regarding the forensic use of DNA technologies, namely the dialogues established between the police investigators and the forensic laboratories, rendering specific and situated forms of knowledge and expertise that illustrate the socially constructed dimensions of the forensic uses of DNA technologies (Cole and Lynch 2006; Cole 2012). A first section of this paper will provide a synthesis of the sample of criminal cases on which this analysis is grounded. The second section will draw on examples from each case in order to conceptualize the general stances of the actors and their institutions. I will argue that, on the one hand, the police investigators' discourse reveals what I have called "evidentiary pragmatism" while, on the other hand, reports from the forensic experts can be characterized by its "epistemic distancing".

The Portuguese criminal justice system is, like many other continental justice systems, oriented by an inquisitorial principle. A common feature is that the "search for the truth", constitutes the ultimate objective of any criminal investigation and judicial proceeding. When a crime is detected, it is reported to the competent entity, which is the prosecution service (Ministério Público - MP), that will coordinate the inquiry with the assistance of the criminal police agencies. These agencies (Polícia Judiciária - PJ; Polícia de Segurança Pública - PSP and the Guarda Nacional Republicana - GNR) may perform the necessary actions and diligences for the development of the investigation, under the supervision of the judiciary authority. The most serious and/or complex crimes (defined by Law 48/2008) fall under the exclusive competence of the Polícia Judiciária (PJ).

In an inquisitorial justice system, the police, the prosecution, the judges, and also the laboratories, are all regarded as fully impartial (Kruse 2012). In this judicial edifice, trial judges are legally considered to be the ultimate expert in evaluating and interpreting the evidence brought before the court. Nevertheless, as stated in article 163 of the Portuguese Code of Criminal Procedure (2007), technical, scientific or artistic evidence are not the subject of free interpretation by the trial judge. That is, if for some 
reason, the judge does not agree with the expert(s), he or she must be prepared to fundament their disagreement. The court can always demand further clarification regarding forensic exams, and the defense can submit requests to the judge for new forensic exams or enroll a forensic expert as witness.

In summary, the police performs the investigation of a crime under the supervision of the Ministério Público (MP), gathering evidence with the assistance of their own laboratory (LPC - Laboratory of Scientific Police) or the State owned laboratory (INMLCF - National Institute of Legal Medicine and Forensic Science). When the police concludes the inquiry, the MP has to evaluate the facts, classify the type of crime(s) and, if the inquiry has led to the identification of suspects, if there is enough evidence to produce an accusation. When forensic evidence reaches the courtroom, it is the result of a long chain of events and decisions, and several formal and informal exchanges of information between the police investigators and the laboratory technicians.

During the inquiry, criminal case files are punctuated by reports of the officers on the field, either to the investigation coordinator or to the MP prosecutor. These reports are most informative regarding the ways in which the criminal narrative is developed, containing the known "facts" and the speculative outlines of "what happened", and what is missing from the story. I will use the expression "criminal narrative" in the same manner that Jasanoff (2006) or Kruse (2012) refer to the use of familiar cultural and professional story templates in order to "make sense" of the actors and their actions, and also to interpret the evidence. This is similar to the way Dahl (2007) uses the metaphor of the "jigsaw puzzle" to illustrate the development of a criminal case and the role of DNA in the courtroom, but also to describe the process of construction of DNA evidence. Its construction involves several, as Dahl adequately calls them, "construction workers" in a production line that begins with the offender and will end with the judge and members of the jury. This process of construction is determinant, because:

All of these 'construction workers' may influence how the piece of jigsaw puzzle consisting of DNA evidence is shaped, presented and perceived in a trial. Despite this, DNA is often presented and perceived as an objective truth; a piece of jigsaw puzzle that has only one given size, shape and form (Dahl 2007, 222).

The term "criminal narrative" also conveys the provisional and frequently inductive character, which is inherent to the unfolding development of a criminal 
investigation. A crime scene constitutes a sensitive and precarious object, which became even more so because of the possibilities surrounding the collection of biological traces.

The initial approach to a crime scene is often fundamental for its resolution because it sets in motion a stream of decisions that have to be made with little or no background information. For example, what are the physical boundaries of the crime scene, and how many men, and what sort of equipment should be brought to the crime scene? The first impressions and significances attributed to the initial data is very likely to influence the development of the investigation, which sometimes changes dramatically in face of new evidence. Williams and Johnson $(2007,371)$ refer to a "central impulse" that leads the case investigators to reconstruct a crime's sequence of events by studying signs of activity and movement in the crime scene, and also by applying their professional repertoires about typified criminal behavior. Often, the initial decisions are made by the first officer(s) to arrive on the scene of the crime and the early definition of the situation will help establish a context under which the circumstances, suspects, and traces will be discriminated. Hence, as Kruse argues, pretrial investigations are also drawn around well-known cultural scripts and categories that will play an important role in ascribing meaning to forensic evidence (Kruse 2012).

While there are several approaches by the social sciences to the uses of DNA profiling and databasing technologies, or its uses and significance during trials, ${ }^{1}$ especially in adversarial judicial contexts, its social aspects of the pre-trial investigation in inquisitorial systems are still somewhat peripheral. I will argue that, in analyzing the pre-trial construction of forensic evidence, it is necessary to consider the dialogues established between the police and the laboratories.

\section{Methods}

The criteria for the selection of the criminal cases were that DNA technologies were used in the investigation, that the case files were available to the public - which meant that a sentence had been passed or a decision to end proceedings was reached -, and also that during the investigation and trial the cases received significant and national media coverage - which is relevant in order to analyze the media's discourses

\footnotetext{
${ }^{1}$ See, for example, Social Studies of Science - Special Issue: Contested Identities, 28 (5-6); and also (Lazer 2004; Lynch et al. 2008; Krimsky and Simoncelli 2011; McCartney 2006; Aronson 2007; Machado and Prainsack 2012), and recently the Special Issue of New Genetics and Society - Risky profiles: societal dimensions of forensic uses of DNA profiling technologies (Heinemann, Lemke, and Prainsack 2012).
} 
about DNA technologies, which constitutes another dimension of my wider research. A time interval for selection was established from 1995, which corresponds to the early uses of DNA technologies for criminal investigation purposes in Portugal, and 2010, in order to fulfill the criteria regarding closed cases. During 2012, I visited the courts where the case files were archived and was granted access to them. Each case file was composed of multiple volumes that contained nearly every detail regarding the investigation, as well as the trials and subsequent appeals in almost every case.

Drawing from a grounded theory approach (Glaser and Strauss 1967), and since the number of pages in each case file reached the thousands, I performed an initial selection of the materials that would constitute the corpus of analysis that are either related to each case's progress or, mainly, to the uses of forensic science and DNA technology. Hence, the gathered materials are mainly composed by witness and suspect's testimonies, police reports, forensic reports, official communications between judicial entities, sentences and higher court appeals. I did not collect materials that had no relevant information for the intended purposes, like bulky phone records, bank statements, and common service orders. The next section will provide a brief overview of the context and development of each case.

\section{Five criminal cases}

This section aims to provide the reader with a summary description of each selected case. I will refer to them using the terms and titles that were adopted by the newspapers. However, when citing from the case files I will use the case judicial reference and numbering.

Table 1 - Summary of the selected cases

\begin{tabular}{|c|c|c|c|c|}
\hline $\begin{array}{l}\text { Case } \\
\text { designation }\end{array}$ & $\begin{array}{l}\text { Date of the events - } \\
\text { Judicial sentence (closure) }\end{array}$ & Place & Suspect(s) & $\begin{array}{l}\text { Criminal } \\
\text { typification }\end{array}$ \\
\hline "Meia Culpa" & 16 April 1997 - 1 June 1998 & Amarante & $\begin{array}{l}\text { Álvaro Pinto } \\
\text { Jaime Curval } \\
\text { Octávio Alves } \\
\text { César Fonseca } \\
\text { Aloísio Oliveira } \\
\text { Ricardo Rocha } \\
\text { José Queirós } \\
\text { Artur Santos }\end{array}$ & $\begin{array}{l}\text { Arson [1]; Auto theft } \\
\text { [1]; Aggravated murder } \\
\text { [13]; Attempted } \\
\text { aggravated murder [22] }\end{array}$ \\
\hline "Tó Jó" & 12 August 1999 - 17 April 2001 & Ílhavo & $\begin{array}{l}\text { António Jorge } \\
\text { Machado (Tó } \\
\text { Jó) } \\
\text { Nuno Lima } \\
\text { Sara Machado }\end{array}$ & Aggravated murder [2] \\
\hline
\end{tabular}




\begin{tabular}{|c|c|c|c|c|}
\hline $\begin{array}{l}\text { Case } \\
\text { designation }\end{array}$ & $\begin{array}{l}\text { Date of the events - } \\
\text { Judicial sentence (closure) }\end{array}$ & Place & Suspect(s) & $\begin{array}{l}\text { Criminal } \\
\text { typification }\end{array}$ \\
\hline “Joana" & $\begin{array}{l}\text { 12 September } 2004-11 \\
\text { November } 2005\end{array}$ & Portimão & $\begin{array}{l}\text { João Cipriano } \\
\text { Leonor Cipriano }\end{array}$ & $\begin{array}{l}\text { Aggravated murder [1]; } \\
\text { Hiding a corpse [1] }\end{array}$ \\
\hline $\begin{array}{l}\text { "Serial Killer of } \\
\text { Santa Comba } \\
\text { Dão" }\end{array}$ & $\begin{array}{l}24 \text { May } 2005 \text { (disappearance of } \\
\text { the first victim) - } 31 \text { July } 2007\end{array}$ & $\begin{array}{l}\text { Santa } \\
\text { Comba Dão }\end{array}$ & $\begin{array}{l}\text { António Costa } \\
\text { (Tói) }\end{array}$ & $\begin{array}{l}\text { Murder [1]; Aggravated } \\
\text { murder [2]; Hiding a } \\
\text { corpse [2]; Profanation } \\
\text { of a corpse [1]; } \\
\text { Attempted sexual } \\
\text { coercion [2]; Slander } \\
\text { [1] }\end{array}$ \\
\hline $\begin{array}{l}\text { "Madeleine } \\
\text { McCann" }\end{array}$ & $\begin{array}{l}3 \text { May } 2007 \text { - } 21 \text { July } 2008 \\
\text { (Inquiry was closed) }\end{array}$ & Lagos & $\begin{array}{l}\text { Gerald McCann } \\
\text { Kate Healy } \\
\text { Robert Murat }\end{array}$ & $\begin{array}{l}\text { Investigative } \\
\text { hypothesis: }^{2} \\
\text { Abduction for sexual } \\
\text { exploitation or other(s) } \\
\text { (without murder); } \\
\text { Abduction followed by } \\
\text { murder, with or without } \\
\text { hiding the corpse; } \\
\text { Accidental death with } \\
\text { hiding of the corpse }\end{array}$ \\
\hline
\end{tabular}

\section{The "Meia Culpa" case}

The "Meia Culpa" case got its name from the nightclub that was attacked in the night of 16 April 1997. Around 3am, three hooded men entered the nightclub in Amarante (a small city in the North of Portugal) and, using a pistol to intimidate the costumers and staff present at the time, they proceeded to pour petrol all over the bar and furniture, set fire to it, and escaped while locking the main entrance. There were 35 individuals inside and many died trying to open the emergency exit that was locked and sealed. The fire resulted in the immediate death of twelve and in the severe injury of nine. The initial hypothesis pointed towards the possibility of business or personal rivalry as the motivation for the attack, and the investigation sought connections to previous attacks on similar establishments. The "Meia Culpa" case was, and still is, referred to as the most violent crime ever committed in Portugal and it is, probably, the first widely mediatized criminal case in Portugal to involve DNA evidence. The police investigation employed most Judiciary Police (Polícia Judiciária - PJ) agents of the region and also other police forces, like the GNR (Guarda Nacional Republicana). Progress appeared to be quick, as an abandoned car, a jerry can and three balaclavas were found just a few kilometers from the scene of the crime. These objects, as well as others collected in the victims and at the crime scene, were sent to the forensic

\footnotetext{
2 Normally, a case file would list the type of crime being investigated or trialed. However, in the Madeleine McCann case, the abduction hypothesis was considered along with other types of crime.
} 
laboratory for analysis. In spite of all the efforts made by the police, there were no solid clues that could lead to suspects. A breakthrough came when the PJ received an information about a boy that confessed to his mother that he and another boy had stolen a car and that he feared that it had been used in the attack on the nightclub. Following this information, in a matter of a few hours, the police was able to capture the three men that made the attack, as well as the intermediary and the man who commanded the attack.

The case reached trial on February 1998 and, on 1 June 1998, five people were given the maximum sentence (25 years in prison) for the crimes of arson, murder, attempted murder and theft. During the trial, it was proven that the owner of a similar establishment in the same city, José Queirós, was responsible for ordering the attack. The motive was not clearly established during trial, but the three attackers said that there was no intention to kill, just to scare the clients and put the nightclub out of business. The two boys who stole the car that was used in the attack were convicted to one year in prison, suspended for three years.

\section{The “Tó Jó" case}

"Tó Jó", as the case came to be known, was a diminutive for the name António Jorge, a 23-year-old man that, on the night of 12 August 1999 (between 1 and 3am), coinciding with the last solar eclipse of the millennium, stabbed both his parents to death in their home near Aveiro. The father was stabbed many times and his body was found on the upper floor of their house. The mother was also stabbed as she tried to escape and was almost decapitated. The first inspection of the crime scene, as well as the autopsies, revealed haphazard attempts to incinerate the bodies and cleaning of the blood stains. In less than a week, on 16 August 1999, António Jorge was made an arguido $^{3}$ and confessed to have been the sole author of the crimes. However, as suggested by several police reports in the case file, there were several elements that appeared to indicate that the crime had been committed by more than one person. Namely, there was a statement by a witness that said to have seen the family car around

\footnotetext{
${ }^{3}$ Arguido is the legal status attributed to someone against whom has been deduced a formal accusation or process of inquiry. Article 58 of the Portuguese Code of Criminal Procedure states that a person may be made an arguido based on grounded suspicions of crime. The arguido status is designed to provide certain rights, such as knowing the details of the charges or the right to remain silent during interrogations and to have a lawyer present at all times, and obligations that can go from a simple identity and residence statement to preventive prison, even if there is no formal accusation and an investigation is still under way.
} 
6am with two individuals inside; the coroner at the crime scene said that the stab wounds appeared unlikely to have been made by a single person; ${ }^{4}$ and there was the coincidence of the date of the crime with a solar eclipse, associated to the fact that Tó Jó and his wife Sara were members of a black metal band called Agonizing Terror which played songs that allegedly contained satanic lyrics, hence the hypothesis of the crime having been committed in the context of a satanic ritual. This later hypothesis was disregarded by the authorities in their statements to the media, and a motive of financial nature was established since Tó Jó was the sole heir and beneficiary of his parents' life insurance. Nevertheless, the content of the song lyrics and the letters exchanged between band members and their friends from a similar band (often written or signed in blood) led the investigation to suspect the involvement of some of Tó Jó's inner circle of friends. His wife Sara and one of his friends, Nuno, were also accused of involvement in the murders. The trial began on 20 December 1999 and, on 17 April 2001, António Jorge was convicted for the double murder of his parents and sentenced to 25 years in prison, while the other suspects were acquitted.

\section{The "Joana" case}

On 12 September 2004, an 8-year-old girl was reported missing in the village of Figueira in the Algarve. Joana's mother, Leonor Cipriano, reported to the Republican National Guard (GNR) that her daughter had gone to the grocery shop but never returned home, saying she had probably been abducted. There were several police inspections made to Joana's house, but all reported that nothing suspicious was found. It was after the PJ took over the case from the GNR that, on 23 September 2004, following a forensic search of the house - where blood stains were found -, and a police questioning of Leonor, that she and her brother, who was living with them at the time, were considered suspects of having murdered Joana. Both signed statements saying that they were responsible for the, allegedly, accidental death of Joana. Their motives were never clearly established, saying either that Joana caught them having incestuous sexual relations, or that she did not bring the change back from buying the groceries. The mother, Leonor, and her brother João - Joana's uncle - both stated that they punched Joana and that she hit her head. Then, thinking she was dead, they hid the body and told

\footnotetext{
${ }^{4}$ There were no photos of the stab wounds in the case file. Another expert would later testify that it appeared possible that the wounds could have been inflicted by two knives.
} 
everyone that she never came back from the shop and that she might have been abducted.

In the months that followed, the PJ made countless searches for Joana's body. The blood stains that were found inside the house - which remained inhabited after Joana's disappearance and was, in fact, cleaned by Joana's mother using petroleum because of an alleged tick infestation - did not produce relevant matches. When the case reached trial, no traces of Joana's body, blood stains, or the tools allegedly used to cut it to pieces were found. The trial by jury began on 12 October 2005 and, on 11 November 2005, Leonor and her brother João were sentenced to 20 and 19 years and two months in prison, respectively, for the murder and for profanation of Joana's corpse.

\section{The "Serial-Killer of Santa Comba Dão"}

The case that became known as the "Serial-Killer of Santa Comba Dão" refers to the trial of a retired GNR corporal (The Guarda Nacional Republicana (GNR) is a security force which has a military structure and hierarchy) for the murder of three girls in a small town in the centre of Portugal called Santa Comba Dão. The first victim, a 17-year-old who disappeared on 24 May 2005, was discovered by a fisherman on a beach 90 kilometers away on 31 May 2005. The other two victims were reported missing on 14 November 2005 and 8 May 2006. The disappearance of the first victim was not reported by the family, and it was thought that the second victim's disappearance could have been voluntary. The main suspect (António Costa), was well known and esteemed in the community, and took part in a school surveillance program (Escola Segura - Safe School), and even helped in the searches for the girls. The reconstitution of the third victim's routine led the investigation to an isolated pathway where her glasses were found. An inspection of nearby storage buildings led to the collection of biological traces that belonged to the second victim. While the first body was found by the sea, wrapped in plastics, the other two were recovered from a dam, also wrapped in plastics and tied to small cement pillars. A series of coincidences led the investigators to suspect that the three murders were committed by the same individual - someone who knew all the victims and was familiar with their routines. After a search to António Costa's house - which was near the pathway taken by all three victims on the way to their homes - and car, the police found blood of the first and third victim in the boot of his car 
The trial, that took place in Figueira da Foz, began on 4 June 2007 was marked by some contention as to whether the defendant was mentally imputable for the crimes he was accused. António Costa was found guilty on three counts of murder and other crimes. On 31 July 2007, the ex-GNR corporal was sentenced to 25 years in prison.

\section{The "Madeleine McCann" case}

In 2007, a couple of British citizens (Kate and Gerry McCann) were on vacation in the Algarve in a resort in Praia da Luz with their three children (Madeleine 3, Sean and Amelie 2-year-old twins). On May 3, around 10pm Madeleine was said to have "been taken" from the room where the children were sleeping. The initial investigations by the Portuguese police and its crime scene technicians were not able to find traces of Madeleine or a perpetrator. In late July 2007, a British police specialist suggested that there two trained cadaver and blood dogs could be used to search a suspect's house and several vehicles, as well as the surroundings of the holiday apartment. All searches were negative regarding the only suspect - Robert Murat. However, the dogs signaled for blood and human decomposition odors in the McCanns' holiday apartment as well as in their rented car. A forensic team recovered all materials that were likely to have any biological stains and sent them to the Forensic Science Service in Birmingham, UK. The Portuguese laboratories also received some remaining materials for future analysis (pieces of a curtain and plastic trim from the McCanns's rented car).

An informal communication between the laboratory and a liaison officer regarding the preliminary results of the DNA exams on the traces recovered at the apartment and in the car was made available to the Portuguese police (PJ) and, on 6 and 7 September 2007, Kate and Gerald McCann were confronted with numerous questions and with a viewing of the video made of the search dogs marking the scent of blood and cadaver in the apartment and in the car to which both offered no explanation. They were both made arguidos for suspicion of their involvement in their daughter's disappearance. However, the forensic exams did not produce relevant evidence of Madeleine's death. On 21 July 2008, the inquiry on the case was finally closed by the Ministério Público owing to lack of evidence of any crime being committed by the three arguidos in the case.

Drawing examples from the files of the cases described above, the following section will explore the character and conceptualization of the social-legal network by focusing on the dialogues between the police investigators and the forensic laboratories. 


\section{Results}

The Portuguese forensic context is marked by the predominance of two institutions (LPC and INMLCF) which have exclusivity in the provision of forensic services. While the LPC is a department of the Polícia Judiciária, the INMLCF is a state-owned laboratory of legal medicine that performs forensic examinations for the public and private sectors. This is in contrast with the situation in the United Kingdom where the provision of forensic services operates in an open market.

Lawless and Williams (2010) have written about how the privatization of forensic services have shaped new approaches to the interpretation of evidence, namely through the formulation of the Case Assessment and Interpretation (CAI) method. CAI, or the application of bayesian framework of reasoning to criminal case evidence, employs systematic questioning of hypothetical prosecution and defense propositions, generating likelihood ratios in order to assist investigative decision-making. The questions are structured in hierarchical levels that take into account the case's circumstances and assist in the interpretation of the evidence (source, activity, and offence). Ultimately, as Lawless and Williams suggest, "CAI promotes a form of forensic science which renders the criminal investigative process as a form of scientific inquiry itself' (Lawless and Williams 2010, 744).

When observing the Portuguese context, and considering that the studied cases span a period of ten years (1997-2007), it appears that the strategic use of forensic science in criminal investigations is set in a framework of divergent institutional goals between scientists and the police that, particularly in the older cases, can hinder a more efficient and economical use of forensic science.

The following sections will attempt to describe, by using examples drawn from the studied criminal cases, two concepts that can help understand the epistemic tensions that stem from the use of DNA technologies for criminal investigations.

\section{Epistemic distancing}

The role that forensic scientists play in criminal investigations in the Portuguese context is interesting in the sense that, as Amorim has stated (2012a, 266), there is an overlap of two roles: one of criminal investigation, and another of expert witness. Amorim cogently observes that in judicial settings where there the same expert or institution that assists the investigation (analyzing crime scene samples and/or identifying a suspect) also acts as expert witness, is an obvious source of conflict 
(2012a, 268). I argue that this potentially contentious "double role" or role strain tends to be avoided through the laboratory's "boundary work" (Gieryn 1999), which translates in this context to the concept of "epistemic distancing". As the examples drawn from the criminal cases will illustrate, "epistemic distancing" operates through the prevalence of scientific discourse, methods, and logic in face of the cognitive pressures from the judicial system, in order to preserve institutional and scientific credibility. The "distancing" can hinder a more efficient use of forensic technologies in criminal investigations, since it can alienate forensic scientists from the objectives of forensic inquiry. This concept of "epistemic distancing" is intimately related to the concept of "evidentiary pragmatism" which attempts to describe the institutional position of the police towards the contribution of forensic science for the development of the criminal investigation.

The laboratories' epistemic distancing appears configured in three in interconnected dimensions: purification, classification and interpretative limitation. In the reports that are produced and provided to the criminal investigators there is a sense that laboratories actively engage in the protection of their scientific autonomy and in the maintenance of professional standards. In this sense, the dimension of purification illustrates the manner in which the "impure" materials are received and thus transformed into scientific objects of analysis. This transition operates by exhaustive description and classification, covering the biological or physical traces and also the packaging made by the agents on the field. This is mainly done in order to document the chain of custody, but it also carries a symbolic effect which demarcates the police work done on the field from the scientific work of the laboratory.

For example, on the "Tó Jó" case, several biological stains were sent for analysis, and while the official communication that accompanied the objects stated they were blood stains and the places where they were collected, asking for exams to identify the DNA of any suspects, the laboratory report describes the received materials in a way that not only refers to the materials themselves, but also to the specific details of their packaging: ${ }^{5}$

\footnotetext{
...this laboratory has received a white envelope with the stamp of the Polícia Judiciária, closed, with the following writing in black marker pen: "Institute of Legal Medicine, P.M.P. Aveiro". After opening, it contained an envelope, sealed with tape and with the following writings in black marker pen: "Proc, 704/99.9 JAAVR" and within this [envelope] 8 small envelopes
}

\footnotetext{
${ }^{5}$ All translations are responsibility of the author
} 
identical to the previous with the following writings in black marker pen, respectively: "(1) 12.08.99 Zone of the female corpse ground level”, “(2) Stain, male corpse 1st floor 12.08.99”... (704/99.9 JAAVR, p. 804).

This procedure is applied to all materials received by the laboratory. Classification is also a very important element of scientific demarcation. For example, if during the "purification" stage the materials received are said to be blood stains, they are often described as being cotton swabs, pieces of string, or other material, that is stained with a $\mathrm{red} /$ brown color. In order to determine if it is, in fact, blood, presumptive and confirmatory tests are necessary. ${ }^{6}$ Besides the process of selection of stains that occurs at the crime scene, the process of classification will further select what is more likely to render results. In the "Joana" case, following the questioning of the child's uncle - João Cipriano - the PJ made a reconstruction of the crime in which João Cipriano explained what happened and how he and Leonor Cipriano cut Joana's body in three parts and hid it in a small freezer. The important question was where were the body parts hidden. After leading the investigators to search several places in the region, it was also suggested that the body parts could have been fed to pigs in a nearby pig farm. In addition to pig excrements, many clothing items and stains collected from Joana's house, as well as buccal swabs collected from Joana's family members and acquaintances, were sent to the laboratory for analysis. The report, which is forty pages long, details which objects tested positive for blood and/or semen. Many traces were not analyzed because they were classified as having insufficient quantity and/or contaminated. In several objects only the existence of "human blood" is detected and in none of them a profile matching Joana's could be identified.

The dimension regarding the laboratories" "interpretative limitation" illustrates the distinction between the questions asked by the investigation and the answers provided by the laboratories. In other words, the police tends to specify the type of answers they expect and these often direct to binary, yes or no, results. However, the several analyzed forensic reports use a more subtle and indirect language, one which necessarily avoids making claims that go beyond the boundaries of scientific work or might induce categorical interpretations. This is because forensic scientists can offer informal investigative opinions, and there are examples in the files of the studied cases of notes about telephone conversations between forensic analysts and police inspectors that

\footnotetext{
${ }^{6}$ The most frequently used test that is mentioned in the forensic reports is the Kastle-Meyer reaction which consists in the use of a phenolphthalein solution that is colorless in an alkaline solution, turning bright pink when oxidized by peroxide in contact with hemoglobin (Williams and Johnson 2004, 7).
} 
provide suggestions or consider investigative hypothesis. However, any forensic reports that are issued by the laboratories during the investigation become attached to the criminal investigation files and are accounted as evidence, susceptible to evaluation in court.

For example, in the "Serial Killer of Santa Comba Dão" case, the remains of three bodies had to be identified, as well as several stains and other materials collected at the supposed crime scenes (suspect's car and the storage buildings). The laboratory compared the genetic profiles extracted from the victims' remains with the profiles from the samples provided by their parents. The results, which included tables with the genetic profiles of the three contributors, also provided a calculation of the likelihood ratios. Thus, instead of presenting a categorical identification, or an affirmative response, the conclusions of this report are constructed according to a probabilistic interpretation of inclusion or exclusion. For example:

The analysis of the several genetic markers of: [father], [mother], [daughter?]

a) does not allow exclusion of the genetic profile obtained from the blood stain of the unidentified body from belonging to a daughter of the couple [father] and [mother], namely the body of [victim]

b) the statistical analysis led to a likelihood ratio of $L R=722116000000000$. (W=99, $99999999999990 \%$, considering the calculation as if made for paternity and maternity investigation purposes) (29/5.2MAFIG, p. 1460).

However, in one of the analyzed cases (Tó Jó) the delivery of results allowed for interpretative flexibility (Meyer and Schulz-Schaeffer 2006), which produced legal consequences for one of the suspects. As briefly described in the earlier section, this case involved a son that confessed to having murdered his parents. The circumstances of the case (the solar eclipse and the allegedly satanic beliefs of Tó Jó and his friends), and an early presumption that it would be very unlikely for a single person to be capable of inflicting so many stab wounds on two individuals, led to suspicion over Tó Jó's circle of friends. Thus, along with biological traces collected from the crime scene and the car that Tó Jó said he used to escape and simulate a burglary, there were also blood samples collected from two friends (Nuno and Helder) and his wife (Sara). The forensic report includes two tables with a comparison of the eight analyzed genetic markers plus amelogenin belonging to the victims, Tó Jó, Nuno, Helder, Sara, and three of the stains collected at the crime scene and one from the car. Two of the stains (one collected in the bathroom in front of the sink, and another from the inside of the front left door of the 
car) presented mixed profiles. The conclusions for these mixed profiles are presented in the following way:

The profile of the DNA mixture of the stain "(5) WC of the 1st floor" is compatible, for the studied markers, with the simultaneous presence of the profiles of both victims and the suspect Nuno..., albeit not excluding the hypothesis of the presence of the suspects António Jorge[Tó Jó] and Sara (...)

The profile of the DNA mixture of the blood stain in the car is compatible, for the studied markers, with the profiles of both victims and the suspect Nuno (...), without excluding the possibility of the presence of the profile of the suspect António Jorge [Tó Jó] and, eventually, additional "contaminant" biological material (704/99.9 JAAVR, p. 807).

Nevertheless, there was an important detail - that Nuno and Helder said that they had spent a weekend at Tó Jó's parents one month before the crime. However, there was no explanation provided regarding the blood stain in the car. The above examples emphasize the importance of the interpretative limitation in the context of the laboratories "epistemic distancing". A careful reading of the extracted conclusions would advise further analyses or dismissal of those stains. However, when included in the developing criminal narrative, the use of the term "compatible" assumes a more explicit and categorical value. As a result, when Nuno was presented before a judge for inquiry, and confronted with the conclusions of the forensic report, the prosecutor would say that:

The results of the exams made by the Institute of Legal Medicine that prove certain the existence of the suspect's blood in two distinct locations of the victims' house and also in their car, allow us to conclude that Nuno was at the crime scene on the date that the events took place, and that he participated in their commission" (704/99.9 JAAVR, p. 826).

The term "compatibility" that was used in the forensic report of Nuno's genetic profile with two of the stains from the crime scene was interpreted by the prosecution as certainty of Nuno's participation in the crime. Eventually, before the trial, Nuno's lawyer filed a motion to request that the analysis were repeated by a different laboratory (of the same institution, but in a different city). In addition, an external technical consultant drafted new questions and asked to be present in the laboratory to observe the new DNA exams, to which the judge agreed. This is an example of a successful opening of the DNA "black box" and challenging of the dominant interpretation of the evidence, in a situation where it could lead to a wrongful conviction (Dahl 2007). 
The wording of the new forensic report conclusions - which did not contain LR calculations - was constructed in a way that limited potentially incriminating consequences. They explain that "it is not possible for us to draw safe conclusions from the obtained results". Furthermore, the report remarks that, of the two mixtures said to have been found in the car and in the bathroom, only the stain from the car could include a profile which is identical to Nuno's, and that it should render an identical profile to the stain found in the bathroom.

The Madeleine McCann case is probably the most widely publicized criminal case to date, and it had multiple characteristics that contributed to its long media exposure (Machado and Santos 2009, 150). In the analysis of this case, the laboratories' "epistemic distancing" was not as evident as in the previous cases. Although, for example, in the "Serial Killer of Santa Comba Dão" case, there is extensive and thorough documentation of the chain of custody, the three dimensions can be found in the forensic reports. The Portuguese forensic reports from the INMLCF on the Madeleine McCann case have a slightly different approach, since the materials received are not thoroughly described as in earlier cases. This could possibly be attributed to the fact that the materials were collected and sent by the LPC and not from inspectors at the crime scene. Furthermore, there was an extraordinary number of traces that were collected and sent for analysis (hairs, fibers, and samples). In addition, the main report is signed by the directors of all three main national delegations of the INMLCF.

The characteristics of this case make it stand apart from the other selected cases, insofar that it employed the most resources by far and, furthermore, because it involved international cooperation with multiple police forces. The close cooperation with the British police resulted in two very important steps in the investigation: the use of EVRD and CSI $\operatorname{dogs}^{7}$ and the commission of the forensic DNA exams to the Forensic Science Service. The dog's handler and trainer asserted, however, that although the dogs demonstrate through their training capabilities beyond any known forensic equipment or technique, any alert for blood or cadaver odor must always be confirmed in a forensic laboratory. Although the EVRD and CSI dogs were brought to the Algarve to help in searches to the house and garden of the only suspect - Robert Murat - the police decided to perform a search in the Ocean Club apartments and a total of ten vehicles. At this point, the results of the canine inspection are publicly known, as they were widely

\footnotetext{
${ }^{7}$ EVRD - Enhanced Victim Recovery Dog; CSI - Crime Scene Investigation (Human blood search dog)
} 
reported in the media. In order to withdraw from eventual misinterpretations, the dogs' handler filed a report where he described the dogs' reactions and their interpretation. Nevertheless, the summary of the report closes by stating that:

My professional opinion as regards to the EVRD's alert indications is that it is suggestive that this is "cadaver scent" contaminant. This does not how however suggest a motive or suspect as cross contamination could be as a result of a number of given scenarios and in any event no evidential or intelligence reliability can be made from these alerts unless they can be confirmed with corroborating evidence (201/07.0GALGS, p. 2477).

On 4 September, the Portuguese police had access to an informal communication between the laboratory and a liaison officer of the Leicester police. The content was far from categorical and merely suggested, rhetorically, that while some components of the Low Copy Number profile from a dry swab collected from a tile behind the sofa in apartment G5A that was rented by the McCanns, it rendered a mixed profile that made any interpretation too complex:

What we need to consider, as scientists, is whether the match is genuine and legitimate (...) The individual components in Madeleine's profile are not unique to her; it is the specific combination of 19 components that makes her profile unique above all others. Elements of Madeleine's profile are also present within the profiles of many of the scientists here (...) It's important to stress that $50 \%$ of Madeleine's profile will be shared with each parent (...) Therefore, we cannot answer the question: Is the match genuine or is it a chance match? (...) What questions will we never be able to answer with LCN DNA profiling? When was the DNA deposited? How was the DNA deposited? What body fluid(s) does the DNA originate from? Was a crime committed? (201/07.0GALGS, p. 2618).

The nature of this informal communication can also be interpreted as a form of "epistemic distancing" insofar as it emphasizes the boundaries and limits of DNA technology concerning the answer to questions that pertain and are only relevant to the criminal investigation. Thus, the expression "as scientists" marks a distinction between an empirically verified probability of a fact from mere assumption.

This email is also significant because it exposes the differences between a CAI (Case Assessment and Interpretation) paradigm of incorporating forensic evidence into criminal investigations - considering questions from both the prosecution and the defense - from the Portuguese "inquisitorial paradigm", where forensic evidence is sought in order to support the criminal narrative. Acting on this premise, the Portuguese police used the information on the email (a partial match) to confront the McCanns with 
the existence of Madeleine's DNA on places that were signaled by the EVRD and CSI dogs.

The next section will approach the police's "evidentiary pragmatism", which tends to operate on a somewhat contrasting logic from that of the "epistemic distancing”. The institutional functions, concerns, and expectations of the police shape their instrumental use of forensic DNA technologies for criminal investigation purposes. Hence, the police's interpretation of the probative value of DNA should not be separated from their particular interpretation in the context of each criminal case - and this is a central feature of the dialogue between the police and the laboratories, insofar as the police turns to the laboratories' reports for answers that are systematically constructed in a way that transfers the burden of interpretation to the police.

\section{Evidentiary pragmatism}

The first dimension and perhaps the main use of DNA technologies by the police is "identification", that is, to gather as many biological stains as possible, in order to be able to produce working hypothesis about what happened. The initial approach to what has been established as the crime scene is often fundamental for the resolution of the investigation, since it sets in motion a process of discrimination of the traces, individuals, and the relevant information, in frequently chaotic sceneries, where the first impressions and interpretations can influence the course of the investigation. Williams and Johnson $(2007,363)$ refer to a "central impulse" which leads criminal investigators to "reconstruct" the sequence of events that led to the crime. This is performed through professional repertoires of interpretation of the observable signs of movement and activity through the understanding of typified criminal behavior and the general knowledge about each type of crime. However, the early attempts of reconstruction are necessarily rough sketches, made in order to reduce the complexity of a crime scene and focus the investigation on acquiring further details.

It is evident from the analyzed cases that early definitions and interpretations are determinant of the type of inspections and forensic procedures to be adopted. For example, in the Joana case, the purported scenario of an eight-year-old girl that was said to have never returned home after going to the shop 500 meters away led the authorities (GNR) to perform searches in the area. Since Joana was not found, they reported to the PJ - which holds exclusive jurisdiction over the investigation of serious crimes - that a possible abduction could have been made with the use of a vehicle, although there were 
no evident signs of this. Moreover, that the apparent lack of concern by close family members allowed for the hypothesis that Joana was staying with other family members (Joana's biological father had little or no relation with her), and the previous complaints to the Commission for the Protection of Minors presented a likely scenario for this. Hence, the house where Joana lived was first inspected by the PJ five days after the disappearance. Other inspections were made and nothing relevant was found. It was only after suspicion fell upon Joana's mother and uncle that the house was subjected to a forensic inspection - ten days after the disappearance.

As the criminal situation starts to become defined, forensic science is used by the investigation in order to, as Kruse states, materialize "the (criminal) body at the same time as it establishes the connection between a particular body and a particular crime scene" (Kruse 2010, 2). In this sense, the investigation's primary concern is to "identify" bodies and biological traces. This is a prominent element in most requests that accompany biological materials sent to the forensic laboratories. However, particularly in the earlier cases that were selected, and whenever there were no presumable suspects, the laboratories were asked to "perform the adequate exams in order to identify the DNA of eventual suspects" (704/99.9 JAAVR, p. 40). This illustrates the distinct approach to forensic science by the police and the laboratories. Forensic science, and particularly forensic genetics, does not provide "identification".

Forensic genetics can only express probabilities of finding a similar case, and even a high likelihood ratio does not mean that there are individual distinctive features in a genetic profile (Amorim 2012a). One could say that the police's requests for identification are drawn upon the knowledge and practice of traditional forensic sciences that relied on untested claims of the discernible uniqueness (Saks and Koehler 2005). The abstract notion that it is possible to trace a mark to a unique source can be useful for criminal investigators in order to draw strong conclusions in a case (Saks and Koehler 2008). Thus, the dimension of "identification" relates to a pragmatic view, insofar as the investigators are not required to ponder the universality of scientific claims, and it is not the police's concern if a certain profile cannot be identified to the exclusion of all others in the world - only if it will include or exclude a suspect.

As the investigations develop and there are some insights into the network of individuals could have been, legitimately or illegitimately, present at the crime scene, it is possible to provide the laboratories with individual samples for comparison. Identification of the nature and origin of the biological traces is paramount in 
establishing the criminal narrative, insofar as, for example, blood stains are usually interpreted as a sign of a violent crime. Nevertheless, it is important to emphasize that the interpretation and significance of the stains is framed by the context of the ongoing criminal narrative.

The first dimension of "evidentiary pragmatism" is thus connected with the second: causality. This dimension attempts to describe the interpretative process that generally follows the discovery of biological traces, although it can also precede it. What is relevant is that the narrative hypothesis matches the stains at the crime scene and vice-versa. For example, it was after the EVRD and CSI dogs alerted to cadaver and blood scent in the McCanns' holiday apartment that the hypothesis that Madeleine could have died there took shape. By contrast, in a similar case, it was after the PJ took over the Joana case and began suspecting that Joana's mother knew that her daughter was dead - the coordinator of the investigation stated that what caused this suspicion was that Leonor gave an interview in a television show and was wearing black, as is traditional for someone who is in mourning, and that she referred to her daughter in the past tense.

As noted above in the text, it took more than two inspections to the house to find stains that were presumably blood. Hence, causality is the attempt to fit biological traces or other evidence in the story, and vice-versa. In the Joana case, the PJ sought to confirm one of the hypotheses for the location of the child's body - that the body parts could have been fed to pigs. A forensic inspection was carried out in a nearby pig farm, where feces and textile fibers were collected and sent for analysis. A red hat was also found in the vicinity and the investigation tried to connect it to one of the suspects. The steps in the analysis' request explicitly aim to perform the connection between the hat and a particular suspect (excluding all others), asking the laboratory to: "identify biological traces; identify the DNA of the owner of the hat; compare the identified DNA with the DNA of the suspect João...”(330/04.2JAPTM, p. 747). In the Joana case, as well as in others, analysis requests often focus on establishing links between stains and particular individuals, which sometimes reduces the scope of possibilities towards a positive identification.

The value of forensic evidence for criminal investigation can be affected by technical problems like reduced, degraded or contaminated samples. These issues can be potentially aggravated by some degree of cognitive bias in the interpretation, since it is often the same laboratory (and even the same technician) to analyze the stain and the 
suspect sample (Amorim 2012b, 46). Identification is particularly difficult when there are mixture profiles derived from crime scene stains. In the Tó Jó case, the investigation submitted blood stains collected with pieces of string and also provided a group of suspects' samples for comparison. As noted above, the first forensic report stated that the mixed profile was "compatible" with one of the suspect, albeit the presence of other suspects could not be excluded. Nevertheless, the suspect's profile that was thus identified as being "compatible" with the crime scene stains was formally accused and stood trial, in spite of Tó Jó's statements that he had nothing to do with the crime. The case dates from 1999 and since then rules and guidelines have been developed for the interpretation of mixture profiles (Bill et al. 2005). What is relevant here for the "evidentiary pragmatism" perspective is that the "compatibility" of Nuno's profile could be fitted to the criminal narrative, given the existing contextual information (Thompson 2011). Although Tó Jó confessed that he committed both murders alone, there were some inconsistencies in the timeline that he offered and also an eyewitness that stated to have seen two individuals leaving the crime scene in the car that was taken by Tó Jó in order to stage a burglary.

Finally, "legitimation" is expressed through the investigation's use of forensic technologies in order to add or confer an element of scientific credibility or moral authority to a criminal narrative (Cavender and Deutsch 2007; Machado 2012). For example, the "Meia Culpa" case was solved through information given by the mother of one of the suspects, which led to the arrest and subsequent confession by the operatives of the attack on the nightclub. The police found the car and the hoods that were presumably used by three material authors of the crime. The traces were sent for analysis and were followed by hair and blood samples from the three suspects and also of individuals that could be potential contamination sources. The forensic report was produced only a few weeks before the inquiry was closed and the date for the trial was set. Only one of the suspects' profiles - Ricardo - was matched to a small human hair found in one of the hoods. When the case reached trial, it became a matter of asserting the motive of the crime and proving that José Queirós was the moral author of the crime. The connection between Ricardo and the hood was merely a detail that corroborated the confessions and the reconstruction of the crime. However, coincidently, Ricardo was the only of the trio that attacked the nightclub that provided a statement that expressed repentance and pleaded forgiveness from the victims and their families. 
Perhaps the case where "legitimation" in the context of evidentiary pragmatism was most visible and evident was the Joana case. Arguably because this case led to the elaboration of the most complex criminal narrative of the analyzed cases. The narrative, based on the reconstruction made by Joana's uncle, was that Joana came home on the night that she was reported missing, was beaten by her mother and uncle, leaving traces on the walls and near the main entrance. The mother and uncle thought the girl was dead and planned a way to dispose of the body. Then, the suspects said Joana never came home so that other family members would be away from the house, giving them enough time to cut Joana's body in three parts that were hidden in a small freezer in plastic bags. On the following day, the body parts and cutting instruments are said to have been taken to an unknown location and were never recovered. It was not possible to extract DNA profiles from all of the stains sent for analysis and none could be matched to Joana's presumed DNA profile, and the rendered profiles were matched with other family members - including the blood stains that were thought to have resulted from the aggressions on Joana. The forensic report stated that the samples collected in the freezer and on the walls were too small or probably degraded to enable a DNA profile. Nevertheless, the sentence that convicted Joana's mother and uncle found proven that there were Joana's blood stains in the walls and on the floor of the house.

It becomes apparent that the elements that played the prominent role in forming conviction of guilt were other forensic instruments and expert opinions, like the suspects' psychiatric assessments and the medical and veterinary's assessments that legitimated the video reconstruction of the crime performed by Joana's uncle, João Cipriano, and that was exhibited in the courtroom before a jury composed by four citizens. The experts confirmed that the existence of large quantities of blood on the floor resulting from the cutting of Joana's body could have drawn ticks, which justified the scrubbing of the floor with petroleum by Leonor six days after Joana's disappearance, and thus contaminating any biological traces. In addition, the time frame and instruments used cut the body in three pieces, and whether it would fit in the small freezer, were considered at least likely. Ultimately, the judges found that:

The actions described in the reconstruction are compatible with the blood stains collected from the living room (...) these stains are, according to the exams that were made, human blood and mixtures of animal and human blood, and although were insufficient to find out who they belong to, are revealing that something terrible happened in that living room (...) Hence, the stains collected from the living room reinforce the credibility of the reconstruction” (330/04.2JAPTM, p. 637). 
The concept of "evidentiary pragmatism" comes to illustrate a mode of professional reasoning and attainment of institutional purposes that constitutes a dialogical framework towards forensic technology and expertise. In other words, the criminal investigation personnel relates to forensic experts as far as they expect answers to investigative questions that will confirm or conform to the developing criminal narrative. As seen in the above examples (particularly in the Tó Jó and Joana cases), the police's "pragmatism" towards forensic evidence is often biased against a suspect or defendant, insofar as the institutional pressure to solve a case and obtain a conviction can lead to exaggerated inferences.

Another important aspect that emerges from the analysis of the case files is what could be termed as an "authoritative chain of facts" that is embedded in the criminal narrative. That is, as the phases of the criminal procedure advance (inquiry, formal accusation, trial and sentencing), there are some facts that become established and are accepted by the succession of legal actors. This is made evident in the composition of the several documents that tell the story of "what happened" and that often have sections that are copy/paste from previous reports.

\section{Conclusion}

From the analysis of the judicial case files, and particularly the requests for forensic exams, it can be seen that the dialogs between police agents and the laboratories constitute a field of negotiation where organizational objectives and interests are played out. The role of criminal investigators in this negotiation can be characterized by what I propose to be "evidentiary pragmatism". The idea is that criminal investigators ascribe particular and situated interpretations of the traces found at crime scenes, which are rendered, explicitly or implicitly, in the requests that are attached to the traces sent to the laboratories. Necessarily, these requests make sense in the pursuit of a storyline that is being hypothesized as the investigation progresses and a criminal narrative takes shape. Evidentiary pragmatism is thus a manner of establishing a dialogue whereby the formulation of forensic requests discursively implicates the laboratory in the investigative process by stating, more or less explicitly, what would be the "desirable" outcomes of the forensic analyses. Consequently, the evidentiary pragmatism is a form of interpretative flexibility of the outputs generated by forensic laboratories through which task oriented imperatives are performed and achieved. 
The case files themselves are a somewhat "purified" version of the process of criminal investigation, insofar as the full details and order of events are not always comprehensible. These are also inscribed with forensic reports provided to the criminal investigation police and to the cases' prosecutors and investigating judges. Every trace, crime scene stain, suspect sample, or object that is received by the laboratory is subjected to a process of description, categorization, and translation, in order to isolate the materials from all kinds of contaminants, both physical and cognitive. This process has been aptly described in Susana Costa's ethnographic work in a Portuguese forensic laboratory (Costa 2003). This cognitive-instrumental membrane that separates the laboratory from the outside world is important in a socio-legal context where the investigating police, the courts, and the official forensic laboratories are branches of the criminal justice system under the Ministry of Justice. Hence, what I have called the "epistemic distancing" of the forensic laboratories configures a professional ethos marked by distinctions and differentiations from the language, practices, classifications, hypothesis and opinions of the police. Through purification, classification, and interpretative limitation, impure traces, stains and objects collected at crime scenes are scientifically translated in order to deliver "black boxed" results which conform to the organizational needs of the police and the criminal justice system.

While the Portuguese criminal justice system could be characterized by a symbolic submission of law to science (Santos 2000), since expert evidence is not a matter to be freely assessed by the judge, during an investigation that submission is not absolute. Namely, because it is not the trial judge or jury who is to interpret the expert evidence, but the police investigators, prosecutors and investigating judges who will make sense of the laboratory results and inscribe them on the ongoing criminal narrative. Therefore, the process of investigating a crime allows interpretative flexibility along a forensic evidentiary chain until a case reaches trial. At this point, as Helena Machado argues, DNA technologies are perceived as transcendent of the contingencies of human action, and as a symbol of neutrality and truth (Machado 2012, 280). Thus, the authoritative status of DNA technologies is seldom successfully challenged in court, as the complexities and uncertainties surrounding DNA evidence appear "black-boxed" and significantly framed in a criminal narrative that a defense lawyer is rarely prepared to successfully open (Dahl 2007, 234). 


\section{Acknowledgements}

This work was supported by the Fundação para a Ciência e a Tecnologia under Grant [SFRH/BD/72253/2010], and through the project "Forensic DNA databasing in Portugal: Contemporary issues in ethics, practices and policy" [FCOMP-01-0124-FEDER-009231], hosted at the Centre for Social Studies, University of Coimbra, Portugal.

\section{References}

Amorim, Antonio. 2012a. “Opening the DNA Black Box: Demythologizing Forensic

Genetics." New Genetics and Society 31 (3): 259-270. doi: 10.1080/14636778.2012.687083.

Amorim, António. 2012b. "Produção e Interpretação da Prova Genética." In A Ciência

Na Luta Contra o Crime, edited by Helena Machado and Susana Costa, 37-47. Vila Nova de Famalicão: Húmus.

Aronson, Jay. 2007. Genetic Witness: Science, Law, and Controversy in the Making of DNA Profiling. Piscataway, NJ: Rutgers University Press.

Bill, Martin, Peter Gill, James Curran, Tim Clayton, Richard Pinchin, Marcus Healy, and John S. Buckleton. 2005. "PENDULUM-a Guideline-Based Approach to the Interpretation of STR Mixtures.” Forensic Science International 148 (2-3) (March): 181-189. doi:10.1016/j.forsciint.2004.06.037.

Cavender, Gray, and Sarah K. Deutsch. 2007. "CSI and Moral Authority: The Police and Science." Crime, Media, Culture 3 (1) (April): 67-81. doi:10.1177/1741659007074449.

Code of Criminal Procedure. 2007. Approved by Law 78/97, 17 February, Republished by Law 48/2007, 29 August. Portugal: Diário da República. http://www.pgdlisboa.pt/pgdl/leis/lei_mostra_articulado.php?nid=929\&tabela=leis\&f icha $=1 \&$ pagina $=1$.

Cole, Simon A. 2012. "Forensic Culture as Epistemic Culture: The Sociology of Forensic Science.” Studies in History and Philosophy of Biological and Biomedical Sciences (September 26): 1-11. doi:10.1016/j.shpsc.2012.09.003.

Cole, Simon A., and Michael Lynch. 2006. "The Social and Legal Construction of Suspects." Annual Review of Law and Social Science 2 (December): 39-60. doi:10.1146/annurev.lawsocsci.2.081805.110001. 
Costa, Susana. 2003. A Justiça em Laboratório: A Identificação por Perfis Genéticos de ADN. Entre a Harmonização Transnacional e a Apropriação Local. Coimbra: Almedina.

Dahl, Johanne Y. 2007. “Another Side of the Story - Defence Lawyers' Views on DNA Evidence.” In Technologies of inSecurity: The Surveillance of Everyday Life, edited by Katja F. Aas, Helene O. Gundhus, and Heidi M. Lomell, 219-237. Oxon and New York: Routledge-Cavendish.

Gieryn, Thomas F. 1999. Cultural Boundaries of Science: Credibility on the Line. Chicago: University of Chicago Press.

Glaser, Barney G., and Anselm L. Strauss. 1967. The Discovery of Grounded Theory: Strategies for Qualitative Research. New York: Aldine de Gruyter.

Heinemann, Torsten, Thomas Lemke, and Barbara Prainsack. 2012. "Editorial - Risky Profiles: Societal Dimensions of Forensic Uses of DNA Profiling Technologies." New Genetics and Society 31 (3): 249-258. doi: 10.1080/14636778.2012.687132.

Hess, David J. 1997. Science Studies: An Advanced Introduction. New York and London: New York University Press.

Jasanoff, Sheila. 2006. "Just Evidence: The Limits of Science in the Legal Process." Journal of Law, Medicine \& Ethics 34 (2) (January): 328-341. doi:10.1111/j.1748720X.2006.00038.x.

Krimsky, Sheldon, and Tania Simoncelli. 2011. Genetic Justice: DNA Data Banks, Criminal Investigations, and Civil Liberties. New York: Columbia University Press.

Kruse, Corinna. 2010. "Forensic Evidence: Materializing Bodies, Materializing Crimes." European Journal of Women's Studies 17 (4): 1-18. doi: $10.1177 / 1350506810377699$.

Kruse, Corinna. 2012. "Legal Storytelling in Pre-Trial Investigations: Arguing for a Wider Perspective on Forensic Evidence." New Genetics and Society 31 (3): 299309. doi: 10.1080/14636778.2012.687084.

Law 48/2008 of 27 August. 2008. Approves the Law for the Organization of Criminal $\begin{array}{llll}\text { Investigation. } & \text { Portugal: } & \text { daário } & \text { República. }\end{array}$ http://www.dre.pt/pdf1sdip/2008/08/16500/0603806038.PDF.

Lawless, Christopher J., and Robin Williams. 2010. "Helping with Inquiries or Helping with Profits? The Trials and Tribulations of a Technology of Forensic Reasoning." Social Studies of Science 40 (5): 731-55. doi:10.1177/0306312710378787. 
Lazer, David. 2004. DNA and the Criminal Justice System: The Technology of Justice. Cambridge, MA: MIT Press.

Lynch, Michael, Simon A. Cole, Ruth McNally, and Kathleen Jordan. 2008. Truth Machine: The Contentious History of DNA Fingerprinting. Chicago: University of Chicago Press.

Machado, Helena. 2012. “Prisoners' Views of CSI's Portrayal of Forensic Identification Technologies: A Grounded Assessment." New Genetics and Society 31 (3): 271284. doi: 10.1080/14636778.2012.687086.

Machado, Helena, and Barbara Prainsack. 2012. Tracing Technologies: Prisoners' Views in the Era of CSI. Farnham, UK: Ashgate.

Machado, Helena, and Filipe Santos. 2009. "The Disappearance of Madeleine McCann: Public Drama and Trial by Media in the Portuguese Press." Crime, Media, Culture 5 (2): 146-167.

McCartney, Carole. 2006. Forensic Identification and Criminal Justice: Forensic Science, Justice and Risk. Cullompton: Willan Publishing.

Meyer, Uli, and Ingo Schulz-Schaeffer. 2006. "Three Forms of Interpretative Flexibility." Science, Technology \& Innovation Studies Special Issue (1): 25-40. https://eldorado.uni-dortmund.de/handle/2003/26747.

Saks, Michael J., and Jonathan J. Koehler. 2005. "The Coming Paradigm Shift in Forensic Identification Science." Science 309 (5736). AAAS: 892-95. http://www.sciencemag.org/cgi/content/abstract/309/5736/892.

Saks, Michael J., and Jonathan J. Koehler. 2008. "The Individualization Fallacy in Forensic Science Evidence.” Vanderbilt University Law Review 61 (1): 199-219. doi:10.1016/j.forsciint.2004.07.005.

Santos, Boaventura de Sousa. 2000. A Crítica da Razão Indolente: Contra o Desperdício da Experiência. Porto: Afrontamento.

Thompson, William C. 2011. "What Role Should Investigative Facts Play in the Evaluation of Scientific Evidence?” Australian Journal of Forensic Sciences 43 (2-3) (June): 123-134. doi:10.1080/00450618.2010.541499.

Williams, Robin, and Paul Johnson. 2004. "Circuits of Surveillance." Surveillance \& Society 2 (1) (January): 1-14. doi:10.1901/jaba.2004.2-1.

Williams, Robin, and Paul Johnson. 2007. "Trace Biometrics and Criminal Investigations." In Handbook of Criminal Investigation, edited by Tim Newburn, 
Tom Williamson, and Alan Wright, 357-380. Oxon and New York: Willan Publishing. 